\title{
Foliar application of zinc in the agronomic biofortification of arugula
}

\author{
Sergio Manuel RUGELES-REYES ${ }^{1 *}$ (D), Arthur Bernardes CECÍlIO FILHO ${ }^{1}$, Miguel Angel LÓPEZ AGUILAR², \\ Paulo Henrique Soares SILVA ${ }^{1}$
}

\begin{abstract}
Zinc deficiency affects one third of the population and a possible solution is the agronomic biofortification of vegetables. Due to the increased consumption of arugula, this vegetable has good potential of use; however, there are few researches on the subject. The objective of this study was to evaluate the effect of foliar zinc applications, at different times, on physiological, yield, nutritional, and biofortification parameters of the 'Broad Leaf' arugula. Three doses $\left(0.5,1\right.$, and $\left.1.5 \mathrm{~kg} \mathrm{ha}^{-1} \mathrm{Zn}\right) \mathrm{were}^{\mathrm{evaluated}}$ at five times $(15 ; 20 ; 25 ; 15$ and 20; and 15, 20 and 25 days after emergence) and a control treatment. It was observed that there was no effect of the application on the physiological variables, as well as on the height, leaf area, and fresh mass of aerial parts of the plant. Zn sprayings affected the $\mathrm{N}$ contents, while for $\mathrm{Mn}, \mathrm{P}, \mathrm{Cu}$, and $\mathrm{Fe}$, no significant effects were found. It was verified that with the application of $1.5 \mathrm{~kg} \mathrm{ha}^{-1} \mathrm{Zn}$ made at 25 days after emergence, a higher $\mathrm{Zn}$ content was obtained in the arugula leaves, representing an increase of $279 \%$ in relation to the control, showing the effectiveness of foliar zinc applications as an agronomic biofortification strategy for arugula.
\end{abstract}

Keywords: Eruca sativa; foliar fertilization; micronutrient; physiology; yield.

Practical Application: Production of biofortified arugula using foliar application of zinc.

\section{Introduction}

Humans need at least 22 nutrients to maintain a proper and healthy metabolism (White \& Broadley, 2005), with food being the main means of supplying these nutrients. Zinc is part of this group, being classified as a micronutrient with daily requirements of $11 \mathrm{mg}$ for a male adult (National Institutes of Health, 2016). Zn performs several functions, being related to the functioning of the immune system, sensory function, neurobehavioral development, reproductive health, growth, and physical development (Hotz \& Brown, 2004).

Despite their importance in human health, the main foods consumed in developing countries present low levels of micronutrients, making their consumption insufficient to provide the minimum daily requirements (White \& Broadley, 2005).

It is estimated that one third of the world's population is deficient in zinc, which is related to delayed physical and sexual development, skin diseases and anorexia, in addition the risk of infant mortality and reduced work capacity in adults (Muthayya et al., 2013). This situation is attributed to different factors, such as the limited capacity of mineral accumulation in the tissues of interest, as well as food production in soils with low nutrient contents (White \& Broadley, 2009).

Therefore, to solve this problem, different strategies have been developed in the last years to enrich foods. Biofortification is one of them. This technique is defined as the process for producing crops with mineral and vitamin contents that allow to provide nutritional requirements in the human organism (White \&
Broadley, 2005). In this subject, agronomic biofortification is aimed at adding nutrients to the plant through soil, foliar or seed application of fertilizers. It is emphasized that it is a relatively inexpensive and efficient technique to increase the nutritional quality of foods (Saltzman et al., 2013).

The success of agronomic biofortification with zinc is intrinsically related to the way the micronutrient is applied. In some crops of vegetables and fruit trees, the efficiency of soil and foliar application of different $\mathrm{Zn}$ sources has been evaluated. In these studies, increases in micronutrient content and yield were found after foliar application (Mao et al., 2014; Hasani et al., 2012). However, there are still few studies related to agronomic biofortification in leafy vegetables.

In Brazil, in recent years, there has been a diversification in the consumption of vegetables as a consequence of increased income and greater concern for the quality of food (Souza, 2014). Currently, the most planted leafy vegetable is lettuce, however since the end of the 1990s, arugula (Eruca sativa L.) has gained market, with an increase in the quantities marketed, due to its nutritional qualities and the spicy taste of its leaves, which can be served as salads or as a meat accompaniment (Matsuzaki, 2013).

According to Saltzman et al. (2013), the success of biofortification programs depends on the choice of crops that are commonly consumed by the population. Due to the significant increase in the consumption of arugula by the Brazilian population, this crop presents potential for biofortification with zinc. 
Based on the above and due to the lack of research related to the yield and nutritional quality responses of arugula to zinc fertilization, the objective of this study was to evaluate the effect of doses and times of foliar zinc application on yield, physiology and mineral nutrition in biofortification of arugula, in a soil with high nutrient content.

\section{Materials and methods}

\subsection{Location and characteristics of the experimental area}

The experiment was realized at Unesp, Campus Jaboticabal, Sao Paulo (Brazil), located at $21^{\circ} 15^{\prime} 22^{\prime \prime}$ South and $48^{\circ} 18^{\prime} 58^{\prime \prime}$ West, at an altitude of 575 m.a.s.l, from January 26 to March 8, 2017. Mean values of temperature and rainfall during the experiment were obtained from the meteorological station of the FCAV (Figure 1).

The soil of the experimental area is a typical Red Latosol Dystrophic (Embrapa, 2013) of very clay texture, with 615,142 and $243 \mathrm{~g} \mathrm{~kg}^{-1}$ of clay, silt and sand, respectively. Previously to the experiment installation, soil samples were collected from the layer 0-0.2 $\mathrm{m}$ and the chemical characteristics observed were $\mathrm{pH}\left(\mathrm{CaCl}_{2}\right)=5.3$, Organic Matter $=27 \mathrm{~g} \mathrm{dm}^{-3}, \mathrm{Ca}^{2+}=42 \mathrm{mmol} \mathrm{dm}^{-3}$, $\mathrm{Mg}^{2+}=15 \mathrm{mmol}_{\mathrm{c}} \mathrm{dm}^{-3}, \mathrm{~K}^{+}=5.9 \mathrm{mmol}_{\mathrm{c}} \mathrm{dm}^{-3}, \mathrm{P}_{\text {resin }}=9 \mathrm{mg} \mathrm{dm}^{-3}$, $\mathrm{S}=12 \mathrm{mg} \mathrm{dm}^{-3}, \mathrm{~B}=0.27 \mathrm{mg} \mathrm{dm}^{-3}, \mathrm{Cu}=6.1 \mathrm{mg} \mathrm{dm}^{-3}, \mathrm{Fe}=22 \mathrm{mg} \mathrm{dm}^{-3}$, $\mathrm{Mn}=23.1 \mathrm{mg} \mathrm{dm}^{-3}, \mathrm{Zn}=3.1 \mathrm{mg} \mathrm{dm}^{-3}$, cation exchangeable capacity $(\mathrm{CEC})=86.1 \mathrm{mmol}_{\mathrm{c}} \mathrm{dm}^{-3}$ and base saturation $=73 \%$.

\subsection{Treatments and experimental design}

Sixteen treatments were evaluated, which corresponded to the combination of three doses of zinc $\left(0.5 ; 1.0\right.$ and $1.5 \mathrm{~kg} \mathrm{ha}^{-1}$, in foliar application), five application times (15 Days After Emergence DAE, 20 DAE, 25 DAE, 15 and 20 DAE; and 15, 20 and 25 DAE), and a control, equivalent to the absence of $\mathrm{Zn}$ application. It is noteworthy that the evaluated doses of zinc were based on the results of Yuri et al. (2006) and Resende et al. (2008) with the lettuce crop. In the treatments with two and three times of application, $\mathrm{Zn}$ doses were divided proportionally to the number of applications, totalizing in the end the predicted amounts in each treatment.
The experimental design was a randomized complete block with four replicates. The experimental unit consisted of twelve lines of $1 \mathrm{~m}$ in length, separated from each other by $0.25 \mathrm{~m}$ and $0.05 \mathrm{~m}$ between plants. For the evaluation of all the characteristics, the plants located in the eight central lines of each experimental unit were used. The plants of the two lateral lines of the plot and the first and last $0.1 \mathrm{~m}$ of the eight central lines were considered as an edge.

\subsection{Installation and conduction of the experiment}

Before planting, the soil was prepared with one plowing and two harrowing operations, and then the beds were prepared. Liming was not performed, as the soil base saturation was at $73 \%$.

Based on the recommendation of Trani et al. (2014), at planting were applied $40 \mathrm{~kg} \mathrm{ha}^{-1} \mathrm{~N}$ in the form of urea, $400 \mathrm{~kg} \mathrm{ha}^{-1} \mathrm{P}_{2} \mathrm{O}_{5}$ using single superphosphate as a source, and $2 \mathrm{~kg} \mathrm{ha}^{-1}$ of $\mathrm{B}$, as boric acid, sprayed in the soil. $\mathrm{K}$ was not applied, since the nutrient content in the soil was very high.

The sowing of 'Broad Leaf' arugula was carried out on January 26,2017 , directly in the soil, in furrows with $0.02 \mathrm{~m}$ depth. The emergence occurred on February 1, 2017 and when the seedlings presented three leaves, thinning was performed to establish the spacing between plants of $0.05 \mathrm{~m}$. Sprinkler irrigation was realized. Cover fertilizations were performed with urea, applying $120 \mathrm{~kg} \mathrm{ha}^{-1}$ of $\mathrm{N}$ divided in equal amounts at 7, 14 and 21 DAE.

$\mathrm{Zn}$ doses were applied using foliar zinc sulphate application with an adhesive spreader.

The harvest of the experiment was carried out on March 8,2017 , for a total of 36 days after emergence of the seedlings.

\subsection{Characteristics evaluated}

Quantification of chlorophylls and carotenoids: Chlorophyll $\mathrm{a}, \mathrm{b}$ and carotenoids contents $\left(\mathrm{mg} \mathrm{g}^{-1}\right)$ were obtained from plant material stored in a freezer at $-80^{\circ} \mathrm{C}$, from samples collected at 36 DAE. Laboratory procedures were performed according to Lichtenthaler (1987) methodology.

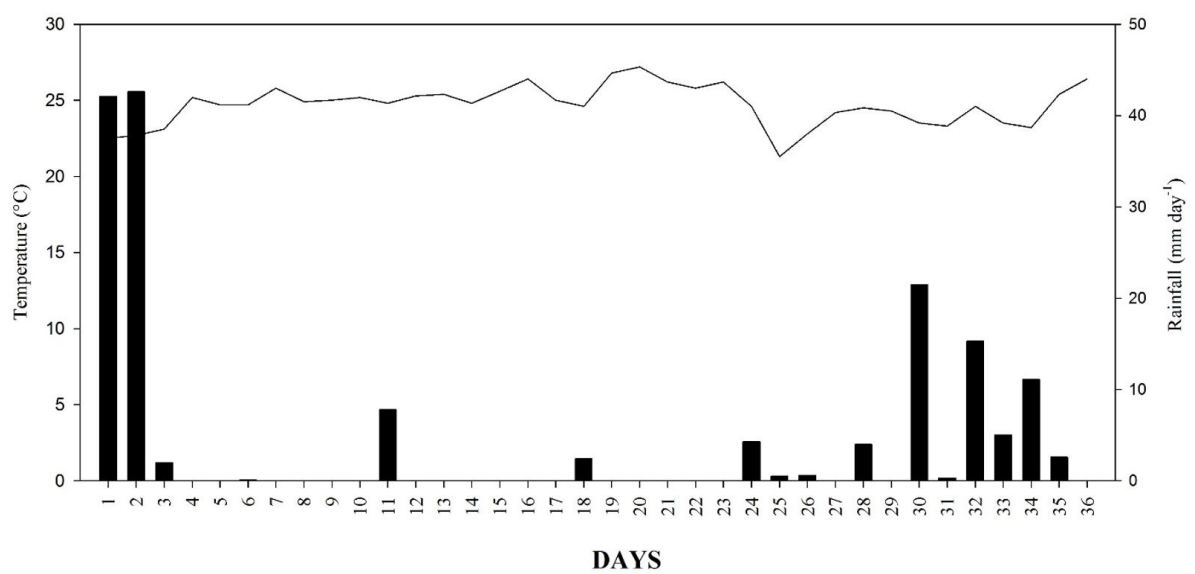

Figure 1. Average temperature and rainfall during the period of the experiment. 
Gas exchange: Using a gas exchange analyzer (IRGA) at 34 and 35 DAE, the following variables were measured: carbon assimilation rate (A) expressed in $\mu \mathrm{mol} \mathrm{m}^{-2} \mathrm{~s}^{-1}$; transpiration (E) in mmol $\mathrm{H}_{2} \mathrm{O} \mathrm{m}^{-2} \mathrm{~s}^{-1}$ and stomatal conductance (gs) expressed in $\mathrm{mol} \mathrm{H}_{2} \mathrm{O} \mathrm{m}^{-2} \mathrm{~s}^{-1}$. The evaluations were performed on leaves from the middle third of the plant, in two plants per plot, during 10 to 12 hours.

Fresh mass of aerial part: At $36 \mathrm{DAE}, 40$ plants were collected from the central part of each plot, within the useful area, by cutting the stem close to the ground. The fresh mass was expressed in g plant $^{-1}$.

Height: In the same plants collected for the determination of fresh mass of aerial part, the height was measured with a millimeter-graduated ruler and expressed in centimeters.

Number of leaves: The number of leaves per plant was counted in the same plants of item 'height'.

Leaf area: For the determination of leaf area $\left(\mathrm{cm}^{2}\right.$ plant $\left.{ }^{-1}\right)$, the Li-Cor 3100 leaf area meter was used.

Dry mass of aerial part: After measuring the leaf area, the samples were washed in water, in neutral detergent solution $\left(3 \mathrm{~mL} \mathrm{~L}^{-1}\right)$, in $0.1 \mathrm{M} \mathrm{HCl}$ solution, followed by washing with deionized water (Miyazawa et al. 2009). Subsequently, the samples were dried in an oven with forced air circulation until constant weight.

Macro and micronutrients content: The dry mass of aerial part was ground in a Wiley mill and prepared for the analysis of macro- $(\mathrm{N}$ and $\mathrm{P})$ and micronutrients $(\mathrm{Zn}, \mathrm{Fe}, \mathrm{Cu}$, and $\mathrm{Mn})$, according to the methods described by Miyazawa et al. (2009).

\subsection{Statistical analyses}

The analysis of variance of the data of each characteristic was realized using the $\mathrm{F}$ test, according to the proposed design. When there was a significant effect of the treatments, a Dunnett test $(p<0.05)$ was performed to establish significant differences with the control, using the statistical software SPSS (version 13.0).

\section{Results}

\subsection{Physiological characteristics}

No effect of the evaluated treatments was observed in transpiration rate (E), stomatal conductance (gs), carbon assimilation (A), or in the contents of chlorophyll a, b and carotenoid, despite the high concentrations of $\mathrm{Zn}$ applied (Table 1).

\subsection{Growth}

The height (HEI), number of leaves (NL), leaf area (LA) and fresh mass of aerial part (FMS) were not influenced by the treatments (Table 2). However, in the dry mass of aerial part (DMS), a significant effect of zinc application was found, observing that the treatment corresponding to the dose of $0.5 \mathrm{~kg} \mathrm{ha}^{-1}$, applied at time 3 , represented an increase of $26 \%$ for this variable in relation to the control treatment.

\subsection{Nutritional status and biofortification}

There was effect of the treatments on leaf $\mathrm{N}$ content (Table 3). It was observed that the application of $0.5 \mathrm{~kg} \mathrm{ha}^{-1}$ at times 2 and 3 , and application of $1 \mathrm{~kg} \mathrm{ha}^{-1}$ at time 1 , presented significant differences in relation to the control treatment, representing

Table 1. Means $(n=4)$ of transpiration $(E)$, stomatal conductance $(g s)$, photosynthetic rate $(A)$, chlorophyll a $($ Clh $a)$, chlorophyll b $($ Clh $b)$ and carotenoids (Car) in arugula plants, submitted to different zinc doses at different times.

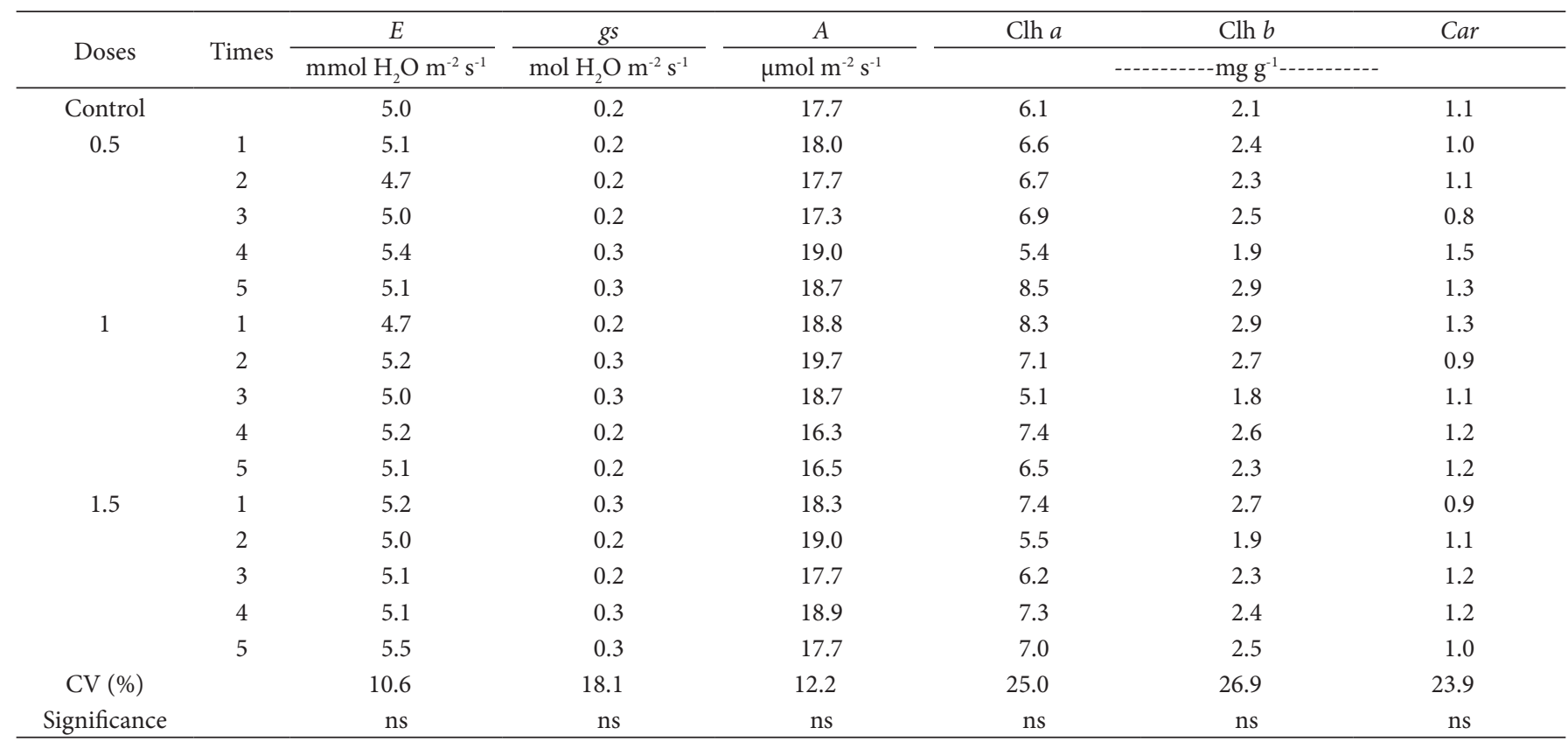

(ns) no significant difference; (+) significant at the $5 \%$ level of probability; (++) significant at the $1 \%$ level of probability, according to the $\mathrm{F}$ test. ${ }^{1}$ Times: 1 ) 15 days after emergence (DAE), 2) 20 DAE, 3) 25 DAE, 4) 15 and 20 DAE, 5) 15,20 and 25 DAE. 
Table 2. Means $(n=4)$ of height (HEI), number of leaves (NL), leaf area (LA), fresh mass of aerial part (FMS) and dry mass of aerial part (DMS) in arugula plants, submitted to different zinc doses at different times.

\begin{tabular}{|c|c|c|c|c|c|c|}
\hline \multirow{2}{*}{ Doses } & \multirow{2}{*}{ Times } & HEI & \multirow{2}{*}{$\begin{array}{c}\mathrm{NL} \\
\text { leaves plant }^{-1}\end{array}$} & \multirow{2}{*}{$\begin{array}{c}\text { LA } \\
\mathrm{cm}^{2} \text { plant }^{-1}\end{array}$} & FMS & DMS \\
\hline & & $\mathrm{cm}$ & & & \multicolumn{2}{|c|}{----g plant ${ }^{-1}----$} \\
\hline Control & & 29.9 & 10.1 & 589.6 & 54.9 & 3.9 \\
\hline \multirow[t]{5}{*}{0.5} & 1 & 30.5 & 10.6 & 566.5 & 58.1 & 4.2 \\
\hline & 2 & 30.8 & 10.7 & 581.0 & 60.5 & 4.5 \\
\hline & 3 & 31.1 & 10.8 & 576.4 & 62.9 & $4.9^{*}$ \\
\hline & 4 & 30.0 & 10.2 & 540.8 & 55.5 & 3.7 \\
\hline & 5 & 31.9 & 11.0 & 572.5 & 61.1 & 4.4 \\
\hline \multirow[t]{5}{*}{1} & 1 & 31.2 & 11.2 & 542.6 & 59.6 & 4.4 \\
\hline & 2 & 30.0 & 10.0 & 554.8 & 51.3 & 3.8 \\
\hline & 3 & 29.8 & 10.2 & 550.3 & 54.7 & 4.0 \\
\hline & 4 & 32.0 & 11.2 & 609.9 & 62.4 & 4.6 \\
\hline & 5 & 30.1 & 10.2 & 568.3 & 56.7 & 4.1 \\
\hline \multirow[t]{5}{*}{1.5} & 1 & 30.8 & 11.0 & 583.7 & 56.7 & 3.9 \\
\hline & 2 & 31.1 & 10.3 & 572.0 & 62.4 & 4.1 \\
\hline & 3 & 29.8 & 10.6 & 519.0 & 54.8 & 3.8 \\
\hline & 4 & 31.6 & 10.8 & 577.3 & 58.8 & 4.1 \\
\hline & 5 & 31.5 & 10.3 & 591.1 & 60.18 & 4.3 \\
\hline CV (\%) & & 5.9 & 11.6 & 11.1 & 12.3 & 10.6 \\
\hline Significance & & ns & ns & ns & ns & + \\
\hline
\end{tabular}

(ns) no significant; (+) significant at the $5 \%$ level of probability; (++) significant at the $1 \%$ level of probability, according to the $\mathrm{F}$ test. ${ }^{*}$ Values are significantly different at $p<0.05$ compared to the control treatment. 'Times: 1) 15 days after emergence (DAE), 2) 20 DAE, 3) 25 DAE, 4) 15 and 20 DAE, 5) 15,20 and 25 DAE.

Table 3. Means $(n=4)$ of N, P, Fe, Cu, Mn and $\mathrm{Zn}$ contents in leaves of arugula plants, submitted to different zinc doses at different times.

\begin{tabular}{|c|c|c|c|c|c|c|c|}
\hline \multirow{2}{*}{ Doses } & \multirow{2}{*}{ Times } & $\mathrm{N}$ & $\mathrm{P}$ & $\mathrm{Cu}$ & $\mathrm{Mn}$ & $\mathrm{Fe}$ & $\mathrm{Zn}$ \\
\hline & & \multicolumn{2}{|c|}{-----g kg-1-.-- } & \multicolumn{4}{|c|}{-- } \\
\hline Control & & 41.7 & 4.2 & 7.5 & 38.3 & 757.8 & 65.0 \\
\hline \multirow[t]{5}{*}{0.5} & 1 & 41.2 & 3.9 & 7.1 & 41.4 & 632.5 & 68.6 \\
\hline & 2 & $49.3^{*}$ & 4.1 & 7.4 & 40.2 & 668.0 & 77.4 \\
\hline & 3 & $48.7^{*}$ & 3.8 & 6.9 & 41.5 & 617.5 & $126.9^{*}$ \\
\hline & 4 & 46.2 & 3.7 & 6.6 & 36.1 & 584.0 & 65.4 \\
\hline & 5 & 44.8 & 3.7 & 6.9 & 37.2 & 575.1 & 87.8 \\
\hline \multirow[t]{5}{*}{1} & 1 & $48.6^{*}$ & 3.9 & 7.3 & 40.1 & 715.0 & 67.8 \\
\hline & 2 & 43.5 & 3.8 & 7.6 & 35.9 & 603.9 & 86.8 \\
\hline & 3 & 44.6 & 3.8 & 7.7 & 38.0 & 617.8 & $209.4^{\star}$ \\
\hline & 4 & 45.3 & 3.7 & 7.3 & 35.2 & 639.2 & 80.1 \\
\hline & 5 & 44.7 & 4.0 & 6.7 & 35.7 & 604.1 & $101.1^{*}$ \\
\hline \multirow[t]{5}{*}{1.5} & 1 & 44.5 & 4.1 & 7.6 & 33.4 & 719.2 & 71.0 \\
\hline & 2 & 43.3 & 4.0 & 7.1 & 36.4 & 609.7 & 88.3 \\
\hline & 3 & 43.8 & 3.9 & 7.5 & 34.6 & 684.2 & $246.5^{*}$ \\
\hline & 4 & 43.0 & 3.9 & 7.4 & 37.8 & 659.78 & 83.9 \\
\hline & 5 & 44.1 & 4.2 & 8.0 & 35.4 & 546.0 & $153.5^{*}$ \\
\hline CV (\%) & & 6.3 & 7.1 & 12.1 & 11.3 & 20.4 & 12.7 \\
\hline Significance & & ++ & ns & ns & Ns & ns & ++ \\
\hline
\end{tabular}

(ns) no significant; (+) significant at the $5 \%$ level of probability; (++) significant at the $1 \%$ level of probability, according to the $\mathrm{F}$ test. ${ }^{*}$ Values are significantly different at $p<0.05$ compared to the control treatment. 'Times: 1) 15 days after emergence (DAE), 2) 20 DAE, 3) 25 DAE, 4) 15 and 20 DAE, 5) 15,20 and 25 DAE.

increases in $\mathrm{N}$ contents of 18,17 , and $16 \%$, respectively. The contents of $\mathrm{P}, \mathrm{Cu}, \mathrm{Mn}$, and Fe were not influenced by the applied treatments (Table 3).

For the $\mathrm{Zn}$ contents found in the arugula leaf, there was effect of zinc application. It was observed that regardless of the dose used, when the application was performed at time 3 , there were differences of these treatments in relation to the control (Table 3). The treatment with the highest leaf content of the micronutrient was the application of $1.5 \mathrm{~kg} \mathrm{ha}^{-1}$ at time 3 (25 DAE), followed by the dose of $1 \mathrm{~kg} \mathrm{ha}^{-1}$ applied at the same time, reaching levels of 246.5 and $209.4 \mathrm{mg} \mathrm{kg}^{-1} \mathrm{Zn}$, which were 279 and $222 \%$ higher than those obtained in plants not sprayed with zinc. 


\section{Discussion}

Several studies report a decrease in chlorophyll content caused by zinc toxicity (Ebbs \& Uchil, 2008). The lack of response to this characteristic can be explained by the zinc doses used, suggesting that the highest dose of the element $\left(1.5 \mathrm{~kg} \mathrm{ha}^{-1}\right)$ was not enough to cause chlorophyll degradation, and the absence of the application was compensated by the high content of $\mathrm{Zn}$ in the soil. In addition, it appears that arugula tolerates high concentrations of zinc without decreasing the levels of photosynthetic pigments (Urlic et al., 2014).

The parameters related to gas exchange can be improved through soil and foliar applications of zinc, notwithstanding, high doses can generate physiological changes, such as low stomatal conductance rates and lower water contents, which favor low rates of carbon assimilation (Sagardoy et al., 2009). The absence of effect found in the present experiment for these parameters suggests a possible compartmentalization of zinc in leaf cells, avoiding damage to physiological processes, which was already verified by Ozdener \& Aydin (2010) in 'Istanbul' arugula, with high concentrations of $\mathrm{Zn}$. In fact, in environments with high concentrations of the nutrient, plants belonging to the family Brassicaceae, such as Brassica oleraceae, can increase the production of organic acids in the leaves, in order to complex the excess zinc, thus preventing damages in their physiology (Barrameda-Medina et al., 2014).

Regarding height, number of leaves, leaf area and fresh mass of aerial part of arugula, there were no effects of zinc doses, agreeing with other studies, in which no influence of the micronutrient was found on the growth of arugula (Ozdener \& Aydin, 2010; $\mathrm{Zhi}$ et al., 2015). It is known that $\mathrm{Zn}$ is a nutrient strongly related to plant growth, since it is necessary for the synthesis of nucleic acids, proteins, and carbohydrates (Marschner, 2012). However, arugula plants not fertilized with $\mathrm{Zn}$ did not differ from the fertilized ones in relation to HEI, NL, LA and FMS, which can be attributed to soil zinc content $\left(3.1 \mathrm{mg} \mathrm{dm}^{-3}\right)$, considered to be very high by Raij et al. (1997), being sufficient to satisfy the nutritional requirement of the micronutrient in arugula. In plants of the same family, several authors verified a positive response to the application of $\mathrm{Zn}$ only when this micronutrient was in a low or medium concentration in the culture medium (Singh \& Bhatt 2013; Lima et al., 2015).

With respect to the dry mass of aerial part, there was effect of the evaluated treatments. The application of $0.5 \mathrm{~kg} \mathrm{ha}^{-1} \mathrm{Zn}$ at time 3 differed from the control. However, no differences were found between the treatments with higher doses of $\mathrm{Zn}$ and the plants without application, ratifying the results observed for the other growth characteristics, in which, even when applying $1.5 \mathrm{~kg} \mathrm{ha}^{-1}$, there was no injury to arugula. These results confirm that species of the family Brassicaceae are little sensitive to high doses of $\mathrm{Zn}$ compared to other families (Barrameda-Medina et al., 2017).

In the present experiment, there was effect of the application of $\mathrm{Zn}$ on $\mathrm{N}$ foliar contents. Zinc is linked to $\mathrm{N}$ metabolism in the plant, since it is correlated with nitrate reductase (NR) activity, besides being a constituent of ribosomes and RNA polymerase (Marschner, 2012). Several studies have shown that due to the deficiency or toxicity of Zn, NR inhibition occurs, leading to a decrease in $\mathrm{N}$ content (Luna et al., 2000); in addition to a decreased incorporation of $\mathrm{N}$ into amino acids and proteins (Sutter et al., 2002). Barrameda-Medina et al. (2016), studying biofortification with zinc in Lactuca sativa L. in hydroponics, found that the dose of $\mathrm{Zn}$ with which the highest activity of the NR enzyme was obtained corresponded to the same dose with the highest leaf $\mathrm{N}$ contents. The results obtained suggest that the doses of $0.5 \mathrm{~kg} \mathrm{ha}^{-1}$ applied at times 2 and 3 , and the dose of $1 \mathrm{~kg} \mathrm{ha}^{-1}$ at time 1 , can improve $\mathrm{N}$ metabolism in arugula plants, increasing the nutrient content in leaves.

Several studies have evaluated the Zn-P interaction, obtaining contrasting results. Singh \& Bhatt (2013), investigating the effect of foliar zinc applications on Lens culinaris, found a reduction in leaf $\mathrm{P}$ content, attributing, as a consequence, the antagonism between the two nutrients. Notwithstanding, Lu et al. (1998), evaluating doses of $\mathrm{Zn}$ in Brassica napus, did not observe effect of zinc on leaf phosphorus contents. The results confirm that the interaction between the two nutrients may be conditioned by the species (Fageria, 2002).

No effect of treatments was observed on leaf $\mathrm{Cu}$ content. Several authors have reported a low relationship between $\mathrm{Cu}$ contents and applied Zn doses (Fageria, 2002; Mao et al., 2014). Lima et al. (2015), working with carrots, okra and cabbage, and increasing doses of $\mathrm{Zn}$ applied to the soil, did not observe effect of $\mathrm{Zn}$ on leaf $\mathrm{Cu}$ contents. Regarding the Mn contents, no effect of the spraying with zinc was observed. Despite that the observed results diverges from several studies that found antagonism between the two nutrients (Imtiaz et al., 2003; Hasani et al., 2012), the effect of zinc on Mn is not well understood and may vary between species (Lima et al., 2015).

The antagonism between $\mathrm{Zn}$ and $\mathrm{Fe}$ is also described in the literature as causing root chelation disorders, as well as competition in the entry of xylem cells (Zhao et al., 2012). However, the absence of $Z n$ effect on leaf iron content, obtained in the present experiment, agrees with several studies done on Brassicaceae species. Wu et al. (2007), studying the tolerance of 158 materials from Brassica rapa $\mathrm{L}$. at high concentrations of $\mathrm{Zn}$, reported a low correlation between leaf iron and zinc contents in plants moderately and highly tolerant to the micronutrient. Neriman et al. (2011), carrying out the nutritional characterization of 30 arugula samples from different locations, did not verify correlation between zinc and iron contents in the leaf. On the other hand, it is noted that with the highest dose of applied zinc, no Fe deficiency was observed, a factor that would also explain the lack of effect on chlorophyll $a$ and $b$ contents, since, according to Ebbs \& Uchil (2008), iron deficiency due to high doses of Zn is one of the causes of the decrease in chlorophyll values.

There was an effect of zinc application on leaf $\mathrm{Zn}$ content. In the five treatments that presented significant differences in relation to the control, spraying was performed at time 3 , at 25 DAE, which, according to Chaves et al. (2010), in the 'Broad Leaf' arugula, corresponds to the period in which there is greater accumulation of fresh mass and higher leaf area growth (21 to 35 DAE). Du et al. (2015), in early growth tomatoes, sprayed zinc during three weeks. The authors found that the content and the absorbed percentage of $\mathrm{Zn}$ of the total applied increased when applications were made in the third week, 
coinciding with the highest value of fresh mass of aerial part between the periods. Kraemer et al. (2009) describe that foliar absorption of nutrients can be improved with increasing leaf surface, as the contact area increases, corroborating the results found in the present experiment.

The $\mathrm{Zn}$ contents in the present study are lower than those reported by Urlic et al. (2014), who worked with the arugula cultivar 'Cultivada' in hydroponics, and found leaf contents of 153.2; 626.5 ; and $864.1 \mathrm{mg} \mathrm{kg}^{-1}$ with the doses of $1 ; 75$; and $150 \mu \mathrm{M} \mathrm{Zn}$, respectively, without observing reduction of dry mass. Ozdener \& Aydin (2010), evaluating the concentrations of 0; 250; 500; 1000; and $2000 \mu \mathrm{g} \mathrm{g}^{-1} \mathrm{Zn}$ in the 'Istanbul' arugula, found leaf contents of 8 ; $24 ; 147 ; 157$; and $251 \mathrm{mg} \mathrm{kg}^{-1} \mathrm{Zn}$, respectively, observing neither toxicity nor reductions in the dry and fresh mass of roots and aerial part.

According to White \& Broadley (2005), the great majority of crops present reduced growth with foliar concentrations higher than $100 \mathrm{mg} \mathrm{kg}^{-1} \mathrm{Zn}$. In the case of leafy vegetables such as lettuce, leaf contents above $218 \mathrm{mg} \mathrm{kg}^{-1} \mathrm{Zn}$, may cause a decrease in the dry mass of roots and aerial part (Barrameda-Medina et al., 2014). The results found in the present study reinforce the hypothesis mentioned by Zhi et al. (2015) that the Eruca sativa is highly tolerant to $\mathrm{Zn}$, being a leafy vegetable with high potential for studies of agronomic biofortification with zinc.

As stated by Barrameda-Medina et al. (2017), aerial part biomass can be used as an indicator to select the $\mathrm{Zn}$ dose in biofortification studies for a specific crop. It should be noted that the $\mathrm{Zn}$ doses evaluated at different times did not cause decreases in HEI, NL, LA, and FMS, although the soil presented a Zn content of $3.1 \mathrm{mg} \mathrm{dm}^{-3}$, considered by Raij et al. (1997) as very high. Thus, all doses of the micronutrient may be considered suitable for biofortification, and do not represent a limitation on the growth of 'Broad Leaf' arugula.

Considering the demand of $11 \mathrm{mg}$ per adult per day (National Institutes of Health, 2016), according to the results observed in Table 3, the highest leaf $\mathrm{Zn}$ content in the dry mass of arugula $\left(246.5 \mathrm{mg} \mathrm{kg}^{-1}\right)$ was obtained with the application of $1.5 \mathrm{~kg} \mathrm{ha}^{-1}$ of the nutrient at the third time, at 25 DAE. Assuming a value of $5 \%$ dry mass in arugula (95\% water), the highest leaf $\mathrm{Zn}$ content (246.5 mg kg $\mathrm{g}^{-1}$ in the dry mass), obtained with the application of $1.5 \mathrm{~kg} \mathrm{ha}^{-1}$ of the nutrient at the third time, at $25 \mathrm{DAE}$, is equivalent to $12.3 \mathrm{mg} \mathrm{kg}^{-1}$ fresh mass, whereas plants that did not receive leaf $\mathrm{Zn}$ presented $3.2 \mathrm{mg} \mathrm{kg}^{-1} \mathrm{Zn}$ in the fresh mass of arugula. Therefore, it is verified that the agronomic practice of foliar fertilization allowed the enrichment of the vegetable in $279 \%$, without affecting crop yield. Consequently, the person consuming $894 \mathrm{~g}$ of arugula in natura would meet his/her daily demand of $\mathrm{Zn}$, while he/she would need 3,438 $\mathrm{g}$ of fresh arugula.

\section{Conclusion}

The foliar application of $1.5 \mathrm{~kg} \mathrm{ha}^{-1}$ zinc at 25 days after emergence, allowed a $279 \%$ increase in micronutrient supply to humans, in comparison to the control. In addition, it was observed that micronutrient spraying did not cause limitations in the growth of 'Broad Leaf' arugula and did not represent alteration in the evaluated physiological processes, even when applied in a soil with a high content of the nutrient. Concluding then that arugula is a specie with high potential for biofortification studies and that foliar applications of the nutrient are effective to increase $\mathrm{Zn}$ contents in the plant leaf.

\section{References}

Neriman, T. B., Mehmet, E. I., \& Mahmut, T. (2011). Mineral contents of the rocket plant (Eruca sativa). African Journal of Biotechnology, 10(64), 14080-14082. http://dx.doi.org/10.5897/AJB11.2171.

Barrameda-Medina, Y., Montesinos-Pereira, D., Romero, L., Ruiz, J., \& Blasco, B. (2014). Comparative study of the toxic effect of $\mathrm{Zn}$ in Lactuca sativa and Brassica oleracea plants: I. Growth, distribution, and accumulation of $\mathrm{Zn}$, and metabolism of carboxylates. Environmental and Experimental Botany, 107(1), 98-104. http://dx.doi.org/10.1016/j. envexpbot.2014.05.012.

Barrameda-Medina, Y., Lentini, M., Esposito, S., Ruiz, J. M., \& Blasco, B. (2016). Zn-biofortification enhanced nitrogen metabolism and photorespiration process in Green leafy vegetable Lactuca sativa L. Journal of the Science of Food and Agriculture, 97(6), 1828-1836. http://dx.doi.org/10.1002/jsfa.7983. PMid:27487980.

Barrameda-Medina, Y., Blasco, B., Lentini, M., Esposito, S., Baenas, N., Moreno, D. A., \& Ruiz, J. M. (2017). Zinc biofortification improves phytochemicals and amino-acidic profile in Brassica oleracea cv. Bronco. Plant Science, 258(1), 45-51. http://dx.doi.org/10.1016/j. plantsci.2017.02.004. PMid:28330562.

Chaves, A. M., Guiscem, J. M., Figuereido, R. T., Rozalino, A. J., Silva, A., Paiva, J. B., \& Santos, F. N. (2010). Avaliação de algumas características de crescimento em rúcula. Horticultura Brasileira, 28(2), 898-904.

Du, Y., Li, P., Nguyen, A. V., Xu, Z. P., Mulligan, D., \& Huang, L. (2015). Zinc uptake and distribution in tomato plants in response to foliar supply of $\mathrm{Zn}$ hydroxide-nitrate nanocrystal suspension with controlled $\mathrm{Zn}$ solubility. Journal of Plant Nutrition and Soil Science, 178(5), 722-731. http://dx.doi.org/10.1002/jpln.201400213.

Ebbs, S., \& Uchil, S. (2008). Cadmium and zinc induced chlorosis in Indian mustard [Brassica juncea (L) Czern] involves preferential loss of chlorophyll b. Photosynthetica, 46(1), 49-55. http://dx.doi. org/10.1007/s11099-008-0010-3.

Embrapa. (2013). Sistema Brasileiro de Classificação de Solos. Rio de Janeiro: Embrapa Solos.

Fageria, N. K. (2002). Influence of micronutrients on dry matter yield and interaction with other nutrients in annual crops. Pesquisa Agropecuária Brasileira, 37(12), 1765-1772. http://dx.doi.org/10.1590/ S0100-204X2002001200013.

Hasani, M., Zamani, Z., Savaghebi, G., \& Fatahi, R. (2012). Effects of zinc and manganese as foliar spray on pomegranate yield, fruit quality and leaf minerals. Journal of Soil Science and Plant Nutrition, 12(3), 471-480. http://dx.doi.org/10.4067/S0718-95162012005000009.

Hotz, C., \& Brown, K. H. (2004). Assessment of the risk of zinc deficiency in populations and options for its control. Toronto: Food and Nutrition Bulletin.

Imtiaz, M., Alloway, B. J., Shah, K., Siddiqui, S. H., Memon, M. Y., Aslam, M., \& Khan, P. (2003). Zinc nutrition of wheat: II: interaction of zinc with other trace elements. Asian Journal of Plant Sciences, 2(2), 156-160. http://dx.doi.org/10.3923/ajps.2003.156.160.

Kraemer, T., Hunche, M., \& Noga, G. (2009). Cuticular calcium penetration is directly related to the area covered by calcium within droplet spread area. Scientia Horticulturae, 120(2), 201-206. http:// dx.doi.org/10.1016/j.scienta.2008.10.015. 
Lichtenthaler, H. K. (1987). Chlorophylls and carotenoids: pigment photosynthetic biomembranes. Methods in Enzymology, 148(1), 350-382. http://dx.doi.org/10.1016/0076-6879(87)48036-1.

Lima, F. S., Nascimento, C. W., \& Sousa, C. S. (2015). Zinc fertilization as an alternative to increase the concentration of micronutrients in edible parts of vegetables. Brazilian Journal of Agricultural Sciences, 10(3), 403-408. http://dx.doi.org/10.5039/agraria.v10i3a5132.

Lu, Z., Grewal, H. S., \& Graham, R. (1998). Dry matter production and uptake of zinc and phosphorus in two oilseed rape genotypes under differential rates of zinc and phosphorus supply. Journal of Plant Nutrition, 21(1), 25-38. http://dx.doi.org/10.1080/01904169809365380.

Luna, C. M., Casano, L. M., \& Trippi, V. S. (2000). Inhibition of wheat nitrate reductase activity by zinc. Biologia Plantarum, 43(2), 257262. http://dx.doi.org/10.1023/A:1002760412055.

Mao, H., Wang, J., Wang, Z., Zang, Y., Lyons, G., \& Zou, C. (2014). Using agronomic biofortification to boost zinc, selenium, and iodine concentrations of food crops grown on the loess plateu in China. Journal of Soil Science and Plant Nutrition, 14(2), 459-470. http:// dx.doi.org/10.4067/S0718-95162014005000036.

Marschner, P. (2012). Marschner's mineral nutrition of higher plants (3. ed.). London: Elsevier.

Matsuzaki, R. T. (2013). Quelatos de ferro afetam o crescimento e a produção de rúcula cultivada em sistema hidropônico (Master's thesis). Universidade de São Paulo, Piracicaba.

Miyazawa, M., Pavan, M. A., Muraoka, T., Carmo, C., \& Melo, W. J. (2009). Análises químicas de tecido vegetal. In Silva F.C. (Eds.). Manual de análises químicas de solos, plantas e fertilizantes (Cap. 2, pp. 191-233). Brasilia: Embrapa.

Muthayya, S., Rah, J. H., Sugimoto, J. D., Roos, F., Kraemer, K., \& Black, R. (2013). The global hidden hunger indices and maps: an advocacy tool for action. PLoS One, 8(1), 1-12. http://dx.doi.org/10.1371/ journal.pone.0067860. PMid:23776712.

National Institutes of Health - NIH. Department of Health \& Human Services. (2016). Office of dietary supplements: Zinc, fact sheet for health professionals. Bethesda: NIH. Retrieved from https://ods. od.nih.gov/factsheets/Zinc-HealthProfessional/

Ozdener, Y., \& Aydin, B. K. (2010). The effect of zinc on the growth and physiological and biochemical parameters in seedling of Eruca sativa (L) (Rocket). Acta Physiologiae Plantarum, 32(3), 469-476. http://dx.doi.org/10.1007/s11738-009-0423-z.

Raij, B. V., Cantarella, H., Quaggio, J. A., \& Furlani, N. A. (1997). Recomendações de adubação e calagem para o Estado de São Paulo (1. ed.). Campinas: Instituto Agronômico de Campinas.

Resende, G. M., Yuri, J. E., \& Souza, R. J. (2008). Épocas de plantio e doses de zinco em alface tipo americana. Horticultura Brasileira, 26(4), 510-514. http://dx.doi.org/10.1590/S0102-05362008000400017.

Sagardoy, R., Morales, F., López-Millán, A. F., Abadía, A., \& Abadía, J. (2009). Effects of zinc toxicity in sugar beet (Beta vulgaris L.) plants grown in hydroponics. Plant Biology, 11(3), 339-350. http://dx.doi. org/10.1111/j.1438-8677.2008.00153.x. PMid:19470105.
Saltzman, A., Birol, E., Bouis, E., Boy, E., De Moura, F., Islam, Y., \& Pfeiffer, H. (2013). Biofortification: Progress toward a more nourishing future. Global Food Security, 2(1), 9-17. http://dx.doi. org/10.1016/j.gfs.2012.12.003.

Singh, A. K., \& Bhatt, B. (2013). Effect of foliar application of zinc on growth and seed yield of late-sown lentil (Lens culinaris). Indian Journal of Agricultural Sciences, 86(6), 622-626.

Souza, E. G. (2014). Produtividade e rentabilidade de Rúcula adubada com espécie espontânea, em duas épocas de cultivo (Master's thesis). Universidade Federal Rural de Pernambuco, Recife.

Sutter, K., Jung, K., \& Krauss, J. (2002). Effects of heavy metals on the nitrogen metabolism of the aquatic moss Fontinalis antipyretica $\mathrm{L}$. ex Hedw: A ${ }^{15} \mathrm{~N}$ tracer study. Environmental Science and Pollution Research International, 9(6), 417-421. http://dx.doi.org/10.1007/ BF02987592. PMid:12515351.

Trani, P. E., Puqueiro, L. F., Figueiredo, G. J., Tivellis, S. W., \& Blat, S. F. (2014). Calagem e adubação da alface, almeirão, agrião d'água, chicória, coentro, espinafre e rúcula (1. ed.). Campinas: Instituto Agronômico de Campinas.

Urlic, B., Dumicic, G., \& Goreta Ban, S. (2014). Zinc and sulfur effects on growth and nutrient concentrations in Rocket. Communications in Soil Science and Plant Analysis, 45(13), 1831-1839. http://dx.doi. org/10.1080/00103624.2014.909829.

White, P. J., \& Broadley, M. R. (2005). Biofortifying crops with essential mineral elements. Trends in Plant Science, 10(12), 586-593. http:// dx.doi.org/10.1016/j.tplants.2005.10.001. PMid:16271501.

White, P. J., \& Broadley, M. R. (2009). Biofortification of crops with seven mineral elements often lacking in human diets- iron, zinc, copper, calcium, magnesium, selenium and iodine. The New Phytologist, 182(1), 49-84. http://dx.doi.org/10.1111/j.1469-8137.2008.02738.x. PMid:19192191.

Wu, J., Schat, H., Sun, R., Koornneef, M., Wang, X., \& Aarts, M. G. (2007). Characterization of natural variation for zinc, iron and manganese accumulation and zinc exposure response in Brassica rapa L. Plant and Soil, 291(1), 167-180. http://dx.doi.org/10.1007/ s11104-006-9184-2.

Yuri, J. E., Resende, G. M., Mota, J. H., Souza, R. J., \& Carvalho, J. G. (2006). Produção de alface americana, em função de doses e épocas de aplicação de zinco. Ciência e Agrotecnologia, 30(1), 665-669. http://dx.doi.org/10.1590/S1413-70542006000400011.

Zhao, H., Wu, L., Chai, T., Zhang, Y., Tan, J., \& Ma, S. (2012). The effect of copper, manganese and zinc on plant growth and elemental accumulation in the manganese hyperaccumulator Phytolacca americana. Journal of Plant Physiology, 169(13), 1243-1252. http:// dx.doi.org/10.1016/j.jplph.2012.04.016. PMid:22796009.

Zhi, Y., Deng, Z., Luo, M., Ding, W., Hu, Y., Deng, J., Li, Y., Zhao, Y., Zhang, X., Wu, W., \& Huang, B. (2015). Influence of heavy metal son seed germination and early seedling growth in Eruca sativa Mill. American Journal of Plant Sciences, 6(5), 582-590. http://dx.doi. org/10.4236/ajps.2015.65063. 